\title{
The Continuing Excesses of Trade Agreements and the Object and Purpose of International Intellectual Property
}

\author{
Susy Frankel
}

Published online: 2 May 2019

(C) Max Planck Institute for Innovation and Competition, Munich 2019

For some time several scholars have repeatedly demonstrated that increased protection of intellectual property can cut across the goals of encouraging innovation and creativity. There has been significant debate about whether innovation and creativity incentives really function as rationales for patent and copyright law respectively. Yet this debate has not halted the progression of increasing standards globally. As an example, some pharmaceutical companies continue to assert that more protection is necessary to support a continuous line-up of incremental developments. Even if one accepts that some protection creates innovation incentives, the same rationale does not automatically correlate to everincreasing levels of protection. There is of course considerable detail to the law, but while debates over details are important, they can also distract from the bigger picture.

National law reforms that utilise the flexibilities of the international regime are often very contentious. Reforms that enable better access to intellectual property products and more user opportunities are relatively few and, where they exist, have been hard fought. Meanwhile, at the international level the one-way ratchet of increasing protection through the use of free trade agreements continues. There have been some significant twists and turns but the direction remains one of increased protection overall.

One twist was the outcome of the Trans Pacific Partnership (TPP), which once finalised did not come into force in the form agreed with the United States. When the United States withdrew from the TPP, in order for the remaining eleven parties to conclude the agreement, many of the controversial intellectual property provisions were suspended and the agreement was renamed the Comprehensive and Progressive Trans-Pacific Partnership. The suspended provisions included 
copyright term extension, provisions relating to the scope of technological protection mechanisms in copyright, patent term extension of pharmaceuticals, defined periods of regulatory data exclusivity for new pharmaceuticals including biologics, and the requirement of patentability for second uses of known compounds. ${ }^{1}$ Many of the suspended provisions have reappeared in the ongoing negotiations, such as the Regional Cooperation Economic Partnership among the ASEAN countries and China, Japan, India, South Korea, New Zealand and Australia. The final details of that agreement remain to be seen, but many of the nations involved in the negotiations are unlikely to agree to some of the details found in the TPP. For example, given India's stance against expanded protection for pharmaceuticals it seems unlikely that it would agree to terms that would require it to amend the controversial Sec. 3(d) provision of its Patent Act, which prohibits second use patents that do not show new properties or efficacy. ${ }^{2}$ The TPP chapter provisions (and particularly those that the CPTPP suspended) have also been reborn, perhaps with a dose of steroids, in the new NAFTA. ${ }^{3}$

While matters such as patent term extension for pharmaceuticals, requirements for second use patents and copyright extension would not bother the EU as they are already its law, none of these plurilateral agreements reflect the EU international negotiaitons priority of geographical indications. In that area the EU progresses its bilaterals to export a geographical indications regime to, for example, Japan, Canada and Singapore. ${ }^{4}$

These and other post-TRIPS agreements will set the new minimum standards should multilateral negotiations ever resume. For those countries whose laws are close to TRIPS minimums, this wave of more extensive protection will be challenging to resist, particularly as trade agreements come not just with intellectual property chapters, but also with chapters that intersect with intellectual property in areas such as investment, pharmaceuticals and more recently digital trade. Increased levels of protection has meant that the object and purpose of intellectual property has evolved a considerable distance, arguably in ways that do not resemble its beginnings, and in ways that are reconceptualising international intellectual property law. ${ }^{5}$

The object and purpose of intellectual property treaties is important as all international agreements must be interpreted in accordance, with the Vienna

\footnotetext{
${ }^{1}$ For an overview of the suspended provisions see New Zealand Ministry of Foreign Affairs, CPTPP v TPP, https://www.mfat.govt.nz/en/trade/free-trade-agreements/free-trade-agreements-in-force/cptpp/understan ding-cptpp/tpp-and-cptpp-the-differences-explained. This also explains the impacts on New Zealand law.

${ }^{2}$ For a discussion of this law see Basheer, Shamnad and Reddy, Prashant, "The 'Efficacy' of Indian Patent Law: Ironing out the Creases in Section 3(d)", (2008) 5 (2) Scripted, Available at SSRN: https:// ssrn.com/abstract $=1086254$.

${ }^{3}$ Agreement Between the United States of America, United Mexican States and Canada, https://ustr.gov/ trade-agreements/free-trade-agreements/united-states-mexico-canada-agreement/agreement-between.

${ }^{4}$ At the time of writing the agreement with Japan is in force, with Canada provisionally in force and Singapore pending final approval, see http://ec.europa.eu/trade/policy/countries-and-regions/negotiationsand-agreements/\#_in-place.

5 See Rochelle Dreyfuss and Susy Frankel, "From Incentive to Commodity to Asset: How International Law Is Reconceptualizing Intellectual Property”, 36 Mich. J. Int’1 L. p. 557 (2015).
} 
Convention on the Law of Treaties. This requires that the ordinary meaning of treaty terms be interpreted in their context and in light of the treaty's object and purpose. The TRIPS Agreement covers most areas of intellectual property and is part of the international trade regime and as such might be said to have multiple objects and purposes. Post-TRIPS trade agreements, for the most part, have taken the goal of protecting profits in export markets to higher levels and, in some instances, these new agreements have left incentive rationales behind, arguably in ways that defy the object and purpose of TRIPS. ${ }^{6}$

It is plausible to argue that the TRIPS Agreement was always somewhat removed from the objectives of innovation and creativity overall or any form of balancing measures, but that conclusion should not be treated as inevitable if proper weight is given to its flexibilities and Arts. 7 and 8 of TRIPS. That said, many knowledgebased products exported by large developed economies continue to be priced considerably above marginal cost, while manufactured goods and raw commodities are more often competitively priced. It is not surprising then that some developing countries have used the inducements of intellectual property to shift their status from intellectual property recipient to powerhouse. The rise of China, for example, has also brought a different approach to more extensive protection with the focus including both widespread patenting and growth in the administration of intellectual property. $^{7}$

The overall object and purpose of the international intellectual property regime is to promote technology transfer, establish local innovation and creative industries and allow governments to incentivise knowledge-based businesses within their borders. Through this lens one could say that it is not only the large developed economies but also some of the large developing economies that have succeeded in the international regime. The problem, however, is that this narrative is fast leaving the medium and small (developed and developing economies) behind. Small market economies of the developed world continue to reap the benefits of innovation, but they also pay higher prices. These economies benefit much more from multilateralism, where they can operate with other blocks of countries, than they do in bilateral or plurilateral negotiations where they have much less negotiating power because they are relatively isolated against large trading powers. The situation is manifestly worse for least-developed countries, some of which have passed detailed intellectual property laws, even when they do not yet have to comply with the TRIPS Agreement. However, investment in local development does not appear to have matched this legislative drive. The motives for this are seemingly mixed and include compliance with agreements with large powers in order to obtain aid, market access and perhaps also stable political relationships.

Increasingly, however, cracks are now forming in the ever-increasing norms coming from the developed world. Developed countries have long been home to some of the greatest challenges to the excesses of the pharmaceutical industry and

\footnotetext{
${ }^{6}$ For an analysis of how aspects of TRIPS-plus trade agreements are contrary to Arts. 7 and 8 see Susy Frankel, "Challenging TRIPS-Plus FTAs - the Potential Utility of Non-Violation Complaints" (2009) 12(4) Journal of International Economic Law pp. 1023-1065.

7 Wenting Cheng and Peter Drahos, "How China Built the World's Biggest Patent Office - The Pressure Driving Mechanism” IIC (2018) 49:5-40, doi:https://doi.org/10.1007/s40319-017-0655-1.
} 
large copyright owners have faced considerable battles from competing forces in their own economies. The current moves in the EU to create an exception to supplementary protection certificates (SPCs) to allow generics (biosimilars in particular) to be manufactured in the EU for export is, on the one hand, a very good policy move to help EU industry. On the other hand, it marks a blatant policy shift from what the EU argued, at the WTO, when it challenged Canada's regime for exporting generic pharmaceuticals. Of course, some will maintain that there are differences (and there are legal distinctions), but the policy goal is equivalent and this new EU approach does contradict its previous stance.

One way to see this example of a change of direction in EU policy is that the effects of too much protection are not just a "developed" versus "developing" matter, but the restrictions that excessive rights place on development also negatively impact industries in developed countries. The approach of adopting intellectual property policy to adjust to domestic priorities is precisely what intellectual property policymakers should be able to do in accordance with the object and purpose of the TRIPS Agreement, which leaves open the possibility to calibrate laws to meet innovation needs. The problem with the ever-increasing protection of trade agreements is that we are starting to see, more often, that those who create such details may be trapping themselves. Those who were at the innovation coalface towards the end of the 20th century maybe experiencing some adverse effects of their own excesses. Those who lead innnovation in the 21st century should be careful what they wish for, as they may also lay a trap for when they are no longer the only dominant players at the innovation frontier. ${ }^{8}$

Publisher's Note Springer Nature remains neutral with regard to jurisdictional claims in published maps and institutional affiliations.

\footnotetext{
${ }^{8}$ See Susy Frankel, "It's Raining Carrots: The Trajectory of Increased Intellectual Property Protection" in Gustavo Ghidini, Hanns Ullrich and Peter Drahos (eds.) Kritika: Essays on Intellectual Property pp. 159-186 (Vol. 2, Edward Elgar, UK, 2017).
} 